\title{
Nitric oxide synthase-mediated early nitric oxide burst alleviates water stress-induced oxidative damage in ammonium-supplied rice roots
}

\author{
Xiaochuang $\mathrm{Cao}^{1+}$, Chunquan Zhu ${ }^{1+}$, Chu Zhong ${ }^{1+}$, Junhua Zhang ${ }^{1}$, Lianghuan Wu ${ }^{2}$, Qianyu Jin ${ }^{1^{*}}$ and Qingxu Ma ${ }^{2^{*}}$
}

\begin{abstract}
Background: Nutrition with ammonium $\left(\mathrm{NH}_{4}^{+}\right)$can enhance the drought tolerance of rice seedlings in comparison to nutrition with nitrate $\left(\mathrm{NO}_{3}{ }^{-}\right)$. However, there are still no detailed studies investigating the response of nitric oxide (NO) to the different nitrogen nutrition and water regimes. To study the intrinsic mechanism underpinning this relationship, the time-dependent production of $\mathrm{NO}$ and its protective role in the antioxidant defense system of $\mathrm{NH}_{4}{ }^{+}$- or $\mathrm{NO}_{3}{ }^{-}$-supplied rice seedlings were studied under water stress.

Results: An early NO burst was induced by $3 \mathrm{~h}$ of water stress in the roots of seedlings subjected to $\mathrm{NH}_{4}{ }^{+}$treatment, but this phenomenon was not observed under $\mathrm{NO}_{3}{ }^{-}$treatment. Root oxidative damage induced by water stress was significantly higher for treatment with $\mathrm{NO}_{3}{ }^{-}$than with $\mathrm{NH}_{4}{ }^{+}$due to reactive oxygen species (ROS) accumulation in the former. Inducing $\mathrm{NO}$ production by applying the $\mathrm{NO}$ donor $3 \mathrm{~h}$ after $\mathrm{NO}_{3}{ }^{-}$treatment alleviated the oxidative damage, while inhibiting the early NO burst by applying the NO scavenger 2-(4-carboxyphenyl)-4,4,5,5-tetramethylimidazoline-1oxyl-3-oxide (C-PTIO) increased root oxidative damage in $\mathrm{NH}_{4}{ }^{+}$treatment. Application of the nitric oxide synthase (NOS) inhibitor N(G)-nitro-L-arginine methyl ester(L-NAME) completely suppressed $\mathrm{NO}$ synthesis in roots $3 \mathrm{~h}$ after $\mathrm{NH}_{4}{ }^{+}$ treatment and aggravated water stress-induced oxidative damage. Therefore, the aggravation of oxidative damage by L-NAME might have resulted from changes in the NOS-mediated early NO burst. Water stress also increased the activity of root antioxidant enzymes (catalase, superoxide dismutase, and ascorbate peroxidase). These were further induced by the $\mathrm{NO}$ donor but repressed by the $\mathrm{NO}$ scavenger and NOS inhibitor in $\mathrm{NH}_{4}{ }^{+}$-treated roots.
\end{abstract}

Conclusion: These findings demonstrate that the NOS-mediated early NO burst plays an important role in alleviating oxidative damage induced by water stress by enhancing the antioxidant defenses in roots supplemented with $\mathrm{NH}_{4}{ }^{+}$.

Keywords: Ammonium, Nitric oxide, Nitric oxide synthase, Oxidative damage, Antioxidant enzymes, Water stress

\section{Background}

As human population and global climate change increase, drought stress is becoming a major abiotic factor limiting crop growth and yield. Plants have evolved several strategies to contend with water stress. These

\footnotetext{
*Correspondence: 11014041@zju.edu.cn; 592214410@qq.com

tXiaochuang Cao, Chunquan Zhu and Chu Zhong contributed equally to this work.

${ }^{1}$ State Key Laboratory of Rice Biology, China National Rice Research Institute, No. 359 Tiyuchang RoadHangzhou, Zhejiang 310006, People's Republic of China

${ }^{2}$ Ministry of Education Key Laboratory of Environmental Remediation and Ecosystem Health, College of Environmental and Resource Sciences, Zhejiang University, Hangzhou 310058, China
}

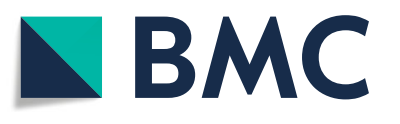

(C) The Author(s). 2019 Open Access This article is distributed under the terms of the Creative Commons Attribution 4.0 International License (http://creativecommons.org/licenses/by/4.0/), which permits unrestricted use, distribution, and reproduction in any medium, provided you give appropriate credit to the original author(s) and the source, provide a link to the Creative Commons license, and indicate if changes were made. The Creative Commons Public Domain Dedication waiver (http://creativecommons.org/publicdomain/zero/1.0/) applies to the data made available in this article, unless otherwise stated.

include morphological, physiological, and molecular adaptations [1-3]. As an important signaling molecule in various physiological functions like seed germination, floral transition, stomatal movement, leaf senescence, and yield development, nitric oxide (NO) has gained increasing attention since the 1980s [4-6]. Certain plant responses and adaptations to abiotic stresses also involve $\mathrm{NO}$, and sufficient data indicate that $\mathrm{NO}$ mediates plant responses to various stimuli including drought [7], salt [8], and metal toxicity [9] stresses, thereby enhancing plant stress tolerance and survival. 
Water deficits simultaneously increase endogenous $\mathrm{NO}$ and reactive oxygen species (ROS) production in plants $[7,10]$. The accumulation of ROS in water-stressed plants impairs the function of biochemical processes, damages organelles, and ultimately results in cell death [11]. A combination of pharmacological analysis and transgenic technology has indicated that NO induces antioxidant activity and alleviates water stress in plants in several ways: (1) It limits ROS accumulation and ROS-induced cytotoxic activity by inhibiting the ROS-producer nicotinamide adenine dinucleotide phosphate oxidase via $S$-nitrosylation [12]. (2) It reacts with $\mathrm{ROS}\left(\right.$ e.g. $\mathrm{O}_{2}{ }^{-}$) to generate transient $\mathrm{ONOO}^{-}$, which is then immediately scavenged by other cellular processes [13]. (3) It induces the expression of genes coding for antioxidant enzymes, such as superoxide dismutase (SOD), ascorbate peroxidase (APX), and glutathione reductase (GR), and may increase enzyme activity, thereby reducing lipid peroxidation under water stress [14]. (4) It helps maintaining high vacuolar concentrations of osmotically active solutes and amino acids like proline [15]. (5) It acts as a downstream abscisic acid (ABA) signal molecule and participates in "ABA- $\mathrm{H}_{2} \mathrm{O}_{2}-\mathrm{NO}-\mathrm{MAPK}$ " signal transduction processes, and thus increases plant antioxidant ability [16]. Therefore, endogenous NO production may enhance plant antioxidant capacity and help plant cells survive under various types of stress.

However, NO has biphasic properties on plants. The duality of its effects depends on stress duration and severity, and on the cell, tissue, and plant species [17]. At low concentration or in the early stage of abiotic stress, NO participates in important functions in higher plants through its involvement in physiological and stress-related processes (as described above). Some authors demonstrated that NO synthesis slightly increased in roots subjected to $<10 \mathrm{~h}$ water deficit, but was significantly up-regulated after prolonged drought $(\geq 17 \mathrm{~h})[18,19]$. Under severe or protracted stress, NO overproduction in plants can shift the cellular stress status from oxidative stress to severe nitrification stress, finally damaging proteins, nucleic acids, and membranes $[13,20]$. Protein tyrosine nitration is considered a good marker to evaluate the process of nitrosative stress under various abiotic stresses [21]. Excess NO can also act synergistically with ROS, resulting in nitro-oxidative stress and eliciting undesirable toxic effects in plant cells [7]. Liao et al. [22] argued that the ability of endogenous or exogenous NO production in plants to alleviate oxidant damage was dose-dependent. Therefore, determining the instantaneous plant NO content under drought stress may not completely reflect the specific role of $\mathrm{NO}$ in drought tolerance.

In higher plants, nitrate reductase (NR) and nitric oxide synthase (NOS) are the two key enzymes for NO production [4, 23]. Moreover, NR-dependent NO production occurs in response to pathogen infection [24], aluminum [25], freezing [26], and drought [27]. For a long time, although NOS-like activity had been detected in plants, the gene(s) encoding NOS protein in higher plants remained to be identified [28]. Recently, some authors demonstrated that mammalian NOS inhibitors suppress NO production in response to various stimuli in plants [22, 29], suggesting that an arginine-dependent NOS activity may also occur in plants. Overexpression of rat neuronal NO synthase in plants increased their tolerance to drought stress, also demonstrating the importance of NOS-mediated NO production in tolerance of water deficits [30]. Arasimowicz-Jelonek et al. [18, 19] applied the NO donor sodium nitroprusside (SNP) and $S$-nitrosoglutathione (GSNO) to water-stressed cucumbers and demonstrated that both NR and NOS participated in drought tolerance. Despite increasing knowledge on NO-mediated plant functions, $\mathrm{NO}$ origins and signaling in response to prolonged stress and their regulation in plant drought tolerance remain poorly understood.

Ammonium $\left(\mathrm{NH}_{4}{ }^{+}\right)$and nitrate $\left(\mathrm{NO}_{3}{ }^{-}\right)$are the two primary $\mathrm{N}$ sources for plants. It is known that the negative effects of drought stress on plant development can be more effectively alleviated by $\mathrm{NH}_{4}{ }^{+}$than $\mathrm{NO}_{3}{ }^{-}$nutrition, as evaluated by plant growth, physiological characteristics, and gene expression levels $[2,31,32]$. NO has a key role in the acclimation of plants to water stress. Nevertheless, information on the dynamic changes in $\mathrm{NO}$ production and its role in drought acclimation in plants supplied with $\mathrm{NO}_{3}{ }^{-}$or $\mathrm{NH}_{4}{ }^{+}$during the early stage of water stress is scarce. In the present study, variations in endogenous $\mathrm{NO}$ production were monitored in roots supplied with these two $\mathrm{N}$ nutrition supplements during water stress. The specific role and origin of the endogenous NO produced were investigated using pharmacological methods. The present study revealed that an early NO burst is crucial for alleviating the water stress-induced oxidative damage through enhancement of antioxidant defenses in roots of $\mathrm{NH}_{4}{ }^{+}$-supplied plants. Further analyses demonstrated that this early NO burst might be triggered by NOS-like enzyme.

\section{Results}

\section{Plant growth and physiological characteristics}

Growth- and physiology-related parameters, such as biomass, net photosynthetic rate $\left(P_{\mathrm{n}}\right)$, and root $\mathrm{N}$ uptake rate in rice seedlings supplied with different $\mathrm{N}$ sources were negatively and differently influenced by water stress (Fig. 1a-f). After 21 days of water stress (as a result of polyethylene glycol [PEG] treatment), root, shoot and total biomass were significantly decreased by 14.1, 62.1 and $52.4 \%$ in treatment with $\mathrm{NO}_{3}{ }^{-}$and PEG, compared to its non-water stress treatment $\left(\mathrm{NO}_{3}{ }^{-}\right.$treatment, as the control treatment) (Fig. 1b, c). However, these values were not significantly affected in $\mathrm{NH}_{4}{ }^{+}$with PEG treatment. Water stress also reduced leaf $\left(P_{\mathrm{n}}\right)$ and $\operatorname{root}{ }^{15} \mathrm{~N}$ 

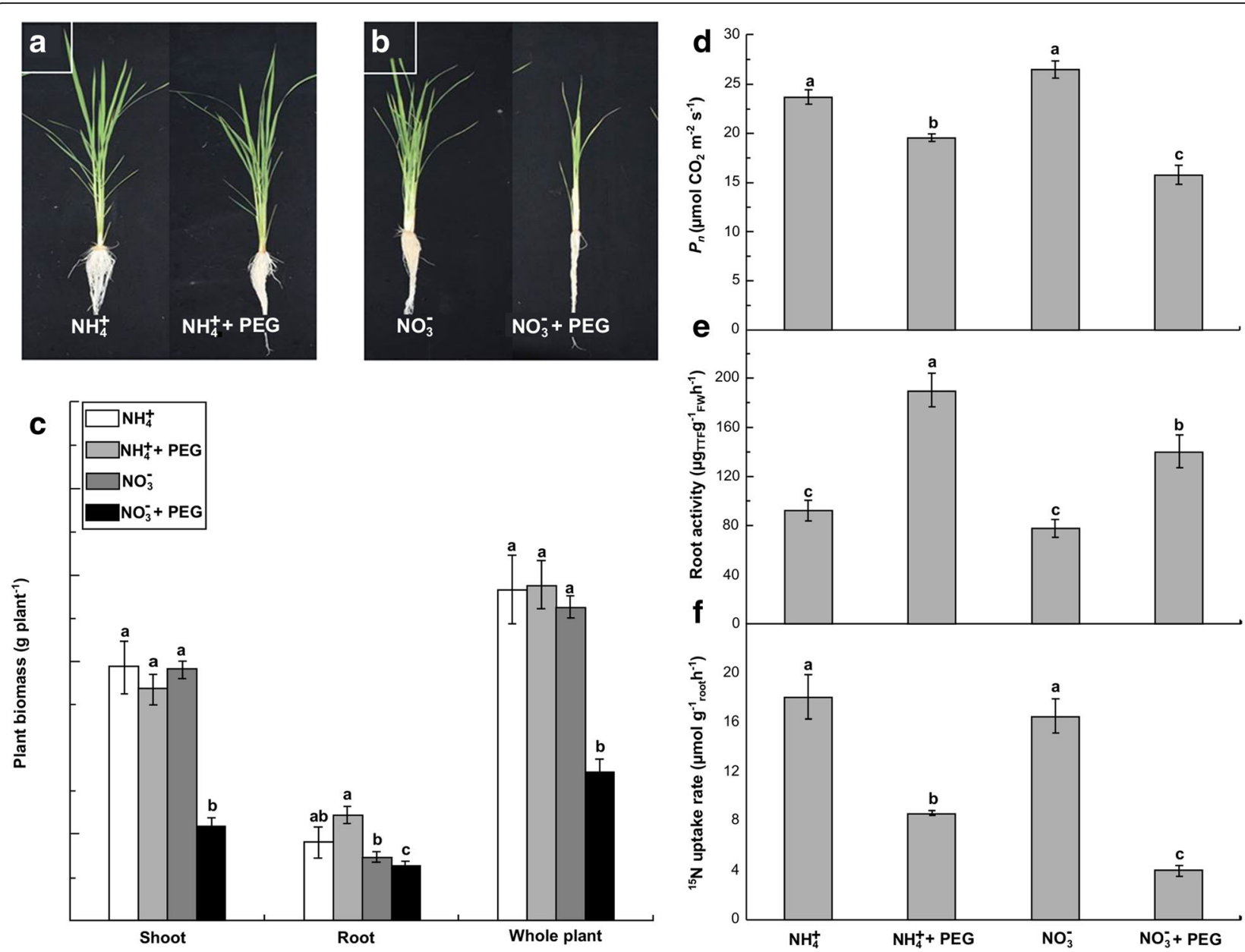

Fig. 1 (a), (b) and (c) Response of rice agronomic characteristics and biomass in $\mathrm{NH}_{4}{ }^{+}$- and $\mathrm{NO}_{3}{ }^{-}$-supplied rice to water stress stimulated by $10 \%$ PEG after 21 days. (d) Effects of water stress on leaf photosynthesis in $\mathrm{NH}_{4}{ }^{+}$- and $\mathrm{NO}_{3}{ }^{-}$-supplied rice after 21 days. (e) Effects of water stress on root activity in $\mathrm{NH}_{4}{ }^{+}$- and $\mathrm{NO}_{3}{ }^{-}$-supplied rice after 21 days. (f) Effects of water stress on root ${ }^{15} \mathrm{~N}$-labeled uptake rate in $\mathrm{NH}_{4}{ }^{+}$- and $\mathrm{NO}_{3}{ }^{-}$-supplied rice after 21 days. Rice leaf photosynthesis, root activity and ${ }^{15} \mathrm{~N}$ uptake rate was determined as described in Additional file 4: Method S1. Values represent means \pm standard error $(\mathrm{SE})(n=6)$. Different letters refer to significant differences at $P<0.05$. TTF: triphenylformazane; FW: fresh weight

uptake rate in the $\mathrm{NO}_{3}{ }^{-}$-treated plants by 40.4 and $76.1 \%(P<0.05)$ in relation to non-water-stress-treated plants, but that of $\mathrm{NH}_{4}{ }^{+}$-treated plants was reduced by 17.3 and $52.2 \%$ (Fig. 1d, f). In contrast, root activity under water stress was increased by 106.2 and $79.6 \%$ in the $\mathrm{NO}_{3}{ }^{-}$-treated and $\mathrm{NH}_{4}{ }^{+}$-treated plants, respectively. Thus, it seems that $\mathrm{NH}_{4}{ }^{+}$-supplied rice seedlings can alleviate PEG-induced water stress more effectively than $\mathrm{NO}_{3}{ }^{-}$-supplied rice seedlings.

\section{Root endogenous NO production and histochemical analyses of oxidative damage}

To investigate whether NO participates in water stress acclimation, endogenous $\mathrm{NO}$ levels in roots were monitored with the NO-specific fluorescent probe diaminofluorescein-FM diacetate (DAF-FM DA) [25]. Significant differences in endogenous NO production were observed in roots after $48 \mathrm{~h}$ of water stress (Fig. 2a). In the $\mathrm{NH}_{4}{ }^{+}$or $\mathrm{NO}_{3}{ }^{-}$-treated plants,
$\mathrm{NO}$ production was relatively stable and varied little between the two N nutritions (Fig. 2b). In contrast, water stress significantly induced endogenous $\mathrm{NO}$ production $3 \mathrm{~h}$ after the roots received $\mathrm{NH}_{4}{ }^{+}$. However, endogenous $\mathrm{NO}$ gradually increased only after $6 \mathrm{~h}$ in the $\mathrm{NO}_{3}{ }^{-}$treatment. Relative fluorescence indicated a significant early burst of $\mathrm{NO}$ at $3 \mathrm{~h}$ of water stress in the $\mathrm{NH}_{4}^{+}$with PEG treatment relative to the $\mathrm{NH}_{4}{ }^{+}$treatment (Con). The NO level in the seedlings treated with $\mathrm{NH}_{4}{ }^{+}$was 2.92 times higher than that of $\mathrm{NO}_{3}{ }^{-}$-treated plants. Nevertheless, $\mathrm{NO}$ in the $\mathrm{NO}_{3}{ }^{-}$-treated seedlings was 2.72 times higher than in $\mathrm{NH}_{4}{ }^{+}$-treated plants after $24 \mathrm{~h}$ of water stress (Fig. 2b).

Histochemical visualization by Schiff's reagent and Evans blue staining showed that water stress caused severe oxidative damage to the plasma membrane and cell death in the roots of the plants receiving $\mathrm{NO}_{3}{ }^{-}$, whereas the damage was far less pronounced in the seedlings given $\mathrm{NH}_{4}^{+}$(Fig. 2c, d). The following analysis of the 


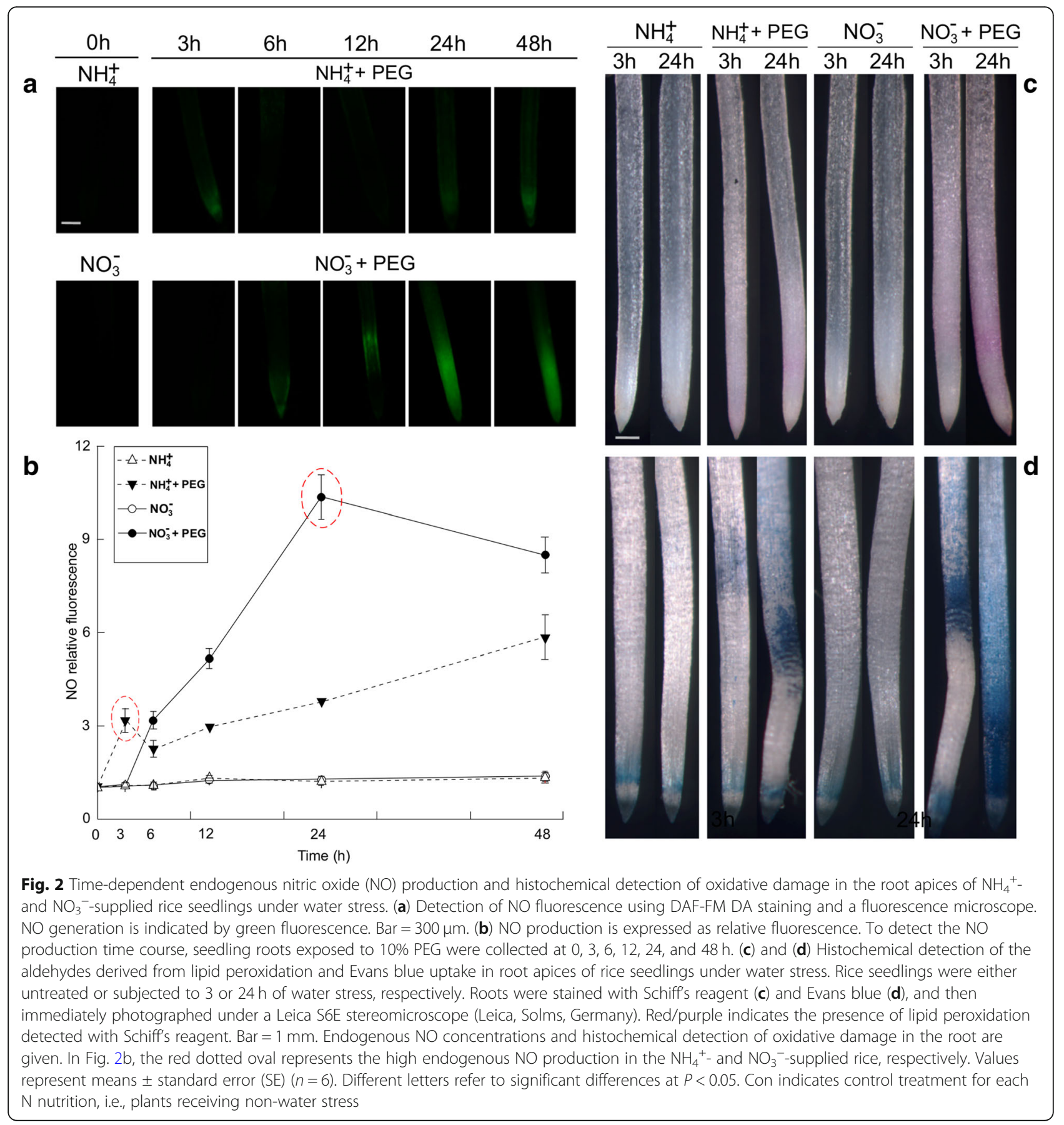

malondialdehyde (MDA) and carbonyl concentrations also confirmed that water stress induced more severe lipid peroxidation in the roots of $\mathrm{NO}_{3}{ }^{-}$-treated than in the roots of $\mathrm{NH}_{4}{ }^{+}$-treated seedlings (Fig. 3c, d).

\section{Effects of the NO donor on root NO production and oxidative damage}

To determine the role of NO in water stress tolerance, the NO donor SNP was used to simulate NO production. Pre-experimentation with various SNP concentrations (0-
$100 \mu \mathrm{M})$ was performed to quantify the efficacy of SNP against root oxidative damage. As shown in Additional file 1: Figure S1, root oxidative damage induced by water stress was significantly alleviated by $\leq 20 \mu \mathrm{M}$ SNP. However, the remedial effect of SNP on root oxidative damage was reversed at higher application doses $(\geq 40 \mu \mathrm{M})$, suggesting that high SNP or NO contents are toxic to root growth. Therefore, $20 \mu \mathrm{M}$ SNP was used in the NO donor experiment conducted in the present study. After $3 \mathrm{~h}$ of water stress, SNP application significantly increased root NO 


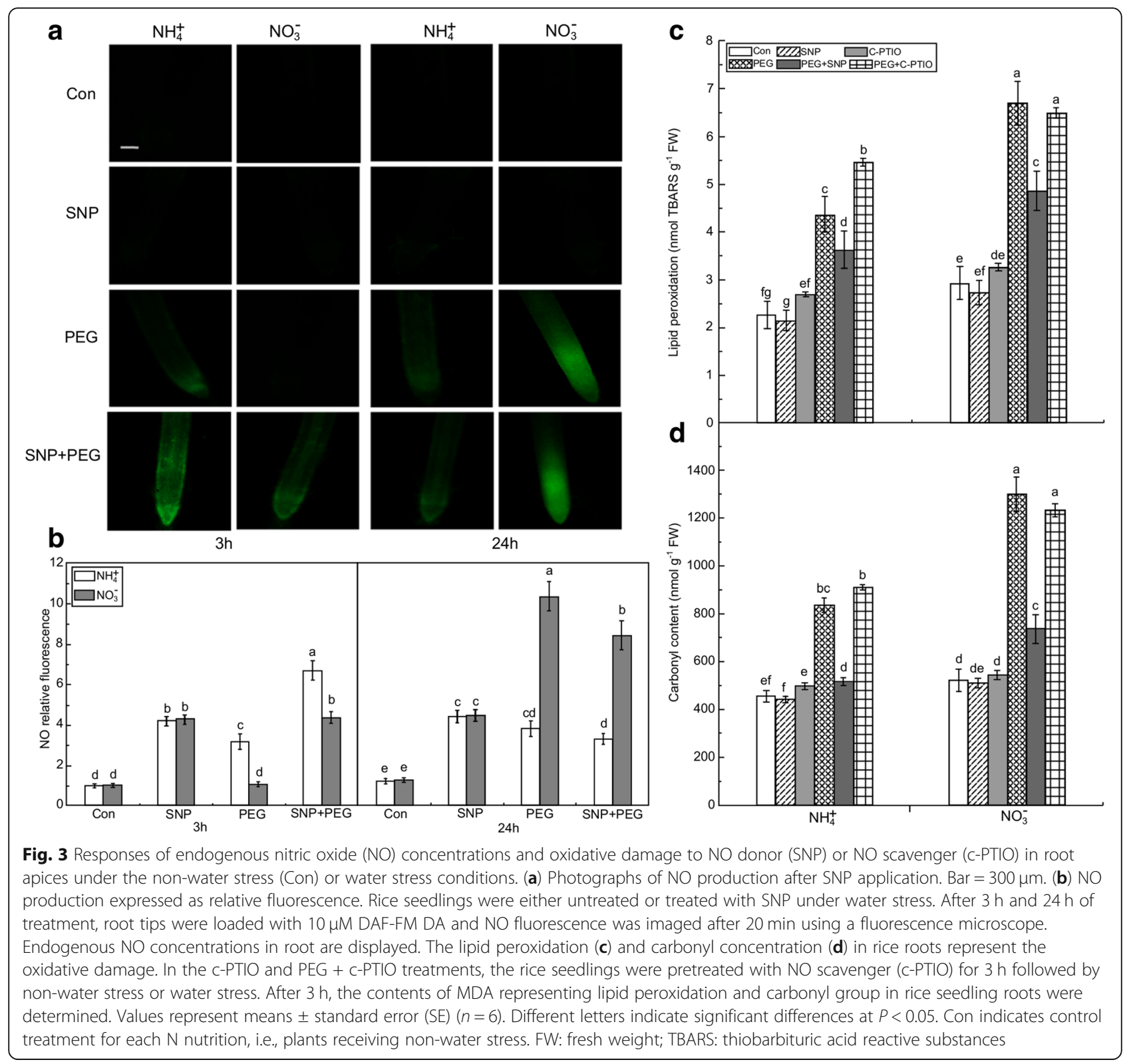

fluorescence intensity for both $\mathrm{N}$ nutrition. At $3 \mathrm{~h}$, the $\mathrm{NO}$ production levels were $\sim 2.05$ and 3.85 times higher in the $\mathrm{SNP}+\mathrm{PEG}$-treated roots of the seedlings receiving $\mathrm{NH}_{4}{ }^{+}$ and $\mathrm{NO}_{3}{ }^{-}$, respectively, than in the PEG-treated roots of Con plants (Fig. 3a, b). However, this phenomenon was not observed after $24 \mathrm{~h}$ of water stress.

After $3 \mathrm{~h}$ of water stress, $\operatorname{ROS}\left(\mathrm{O}_{2}{ }^{-}, \mathrm{H}_{2} \mathrm{O}_{2}\right.$, and $\left.\mathrm{OH}^{-}\right)$ levels were increased in the roots of both the $\mathrm{NH}_{4}{ }^{+}+$PEGand $\mathrm{NO}_{3}{ }^{-}+$PEG-treated seedlings in relation to their Con seedlings. Under water stress, the $\mathrm{O}_{2}^{-}, \mathrm{H}_{2} \mathrm{O}_{2}$, and $\mathrm{OH}^{-}$in the roots given $\mathrm{NH}_{4}{ }^{+}$and $\mathrm{NO}_{3}{ }^{-}$increased by 78.1 and $107.3 \%, 28.3$ and $47.8 \%$, and 10.6 and $48.4 \%$, respectively (Fig. $4 \mathrm{a}-\mathrm{c}$ ). Root MDA and carbonyl contents were $\sim 1.28$ and 1.4 times higher in the plants receiving $\mathrm{NO}_{3}{ }^{-}+\mathrm{PEG}$ than in Con plants, respectively. In turn, MDA and carbonyl levels were significantly higher in $\mathrm{NO}_{3}{ }^{-}+\mathrm{PEG}--$ treated plants than in plants given $\mathrm{NH}_{4}{ }^{+}+$PEG (Fig. 3c, d). Water stress induced higher root $\mathrm{ONOO}^{-}$in the $\mathrm{NH}_{4}{ }^{+}$-treated plants than in the $\mathrm{NO}_{3}{ }^{-}$-treated seedlings (Fig. 4d), and exogenous NO application significantly reduced water stress-induced $>\operatorname{ROS}\left(\mathrm{O}_{2}^{--}\right.$and $\left.\mathrm{H}_{2} \mathrm{O}_{2}\right)$ accumulation and oxidative damage (as reflected by MDA and carbonyl) in both N nutritions (Figs. 3, 4).

To determine whether the alleviation of water stress-induced oxidative damage by SNP was related to $\mathrm{NO}$ production, the NO scavenger c-PTIO was applied to the plants. After pretreatment with $100 \mu \mathrm{M}$ c-PTIO for $3 \mathrm{~h}$, the alleviation of root oxidative damage induced by SNP application under water stress was reversed (Fig. 3c, d). Depletion of endogenous NO by c-PTIO 


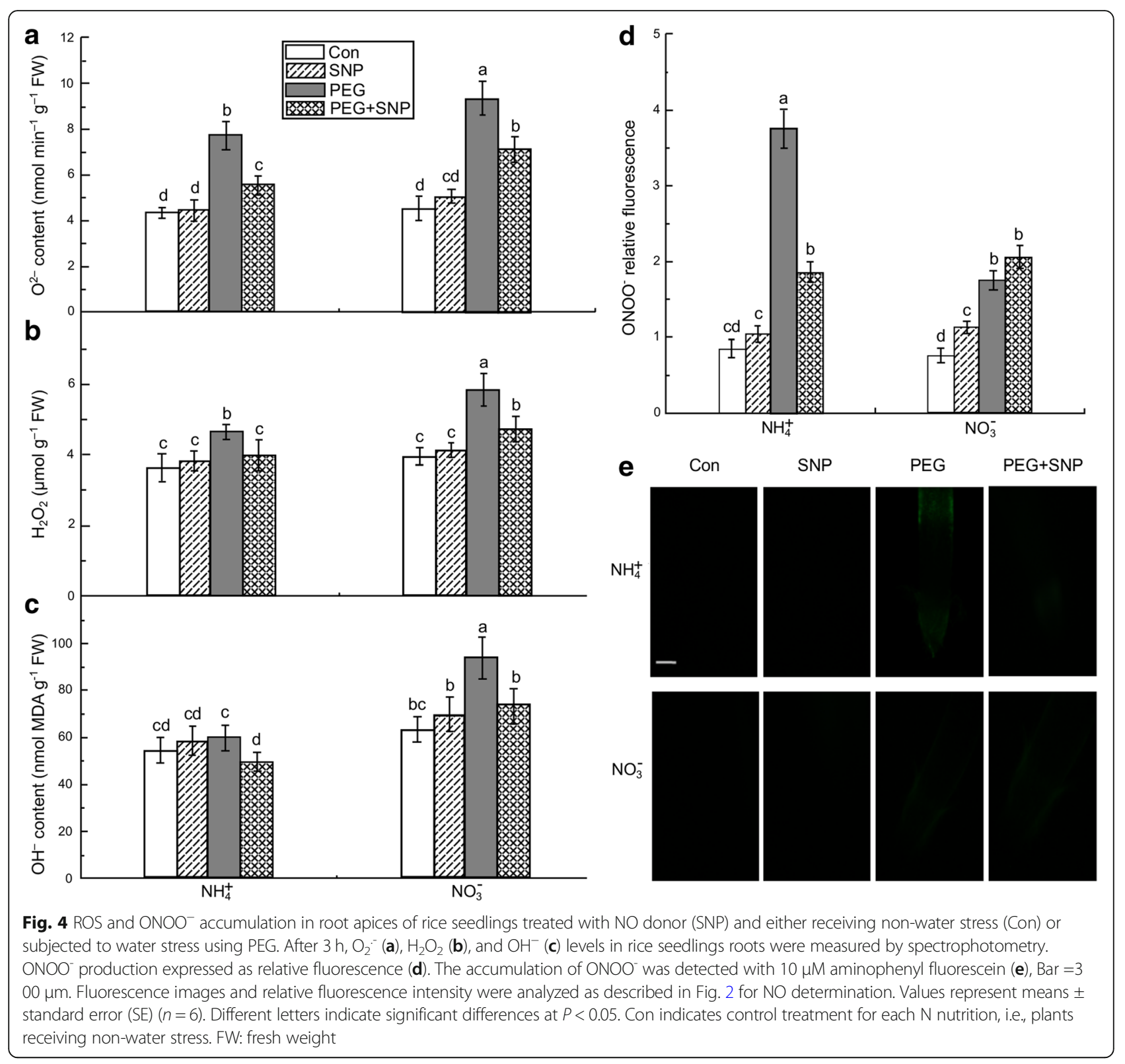

significantly aggravated root oxidative damage in $\mathrm{NH}_{4}{ }^{+}$-treated plants but had no significant effect on the $\mathrm{NO}_{3}{ }^{-}$-treated plants, in relation to that observed in PEG-treated plants. Therefore, the water stress-induced early $\mathrm{NO}$ burst observed in the $\mathrm{NH}_{4}{ }^{+}$-treated plants alleviates root oxidative damage by reducing ROS, such as $\mathrm{O}_{2}{ }^{-}$and $\mathrm{H}_{2} \mathrm{O}_{2}$.

\section{Source of endogenous NO}

Endogenous plant NO production is mostly driven by NR and NOS activity [4]. Water stress increased NR activity in $\mathrm{NO}_{3}{ }^{-}$-treated roots, and this activity was higher at $24 \mathrm{~h}$ than it was at $3 \mathrm{~h}$ of water stress (Additional file 2: Figure S2a). The activity of NOS was also significantly elevated at $3 \mathrm{~h}$ of water stress, and significantly higher in the $\mathrm{NH}_{4}{ }^{+}$-treated than in the $\mathrm{NO}_{3}{ }^{-}$-treated roots (Additional file 2: Figure S2b). In contrast, water stress suppressed NOS activity in $\mathrm{NO}_{3}{ }^{-}$-treated roots at $24 \mathrm{~h}$. Tungstate and L-NAME, which inhibit NR and NOS activities, respectively, were used to identify the origin of the early $\mathrm{NO}$ burst in the $\mathrm{NH}_{4}{ }^{+}$-treated roots [25]. Although L-NAME significantly inhibited endogenous NO production in $\mathrm{NH}_{4}{ }^{+}$-treated roots at $3 \mathrm{~h}$ of water stress, it had no significant effect in the $\mathrm{NO}_{3}{ }^{-}$-treated roots. At $24 \mathrm{~h}$, the tungstate and L-NAME applications suppressed $\mathrm{NO}$ production in $\mathrm{NO}_{3}{ }^{-}$-treated roots, and tungstate had the stronger inhibitory effect. However, tungstate had no significant effect on $\mathrm{NO}$ production in the $\mathrm{NH}_{4}{ }^{+}$-treated roots (Fig. 5a, b). 


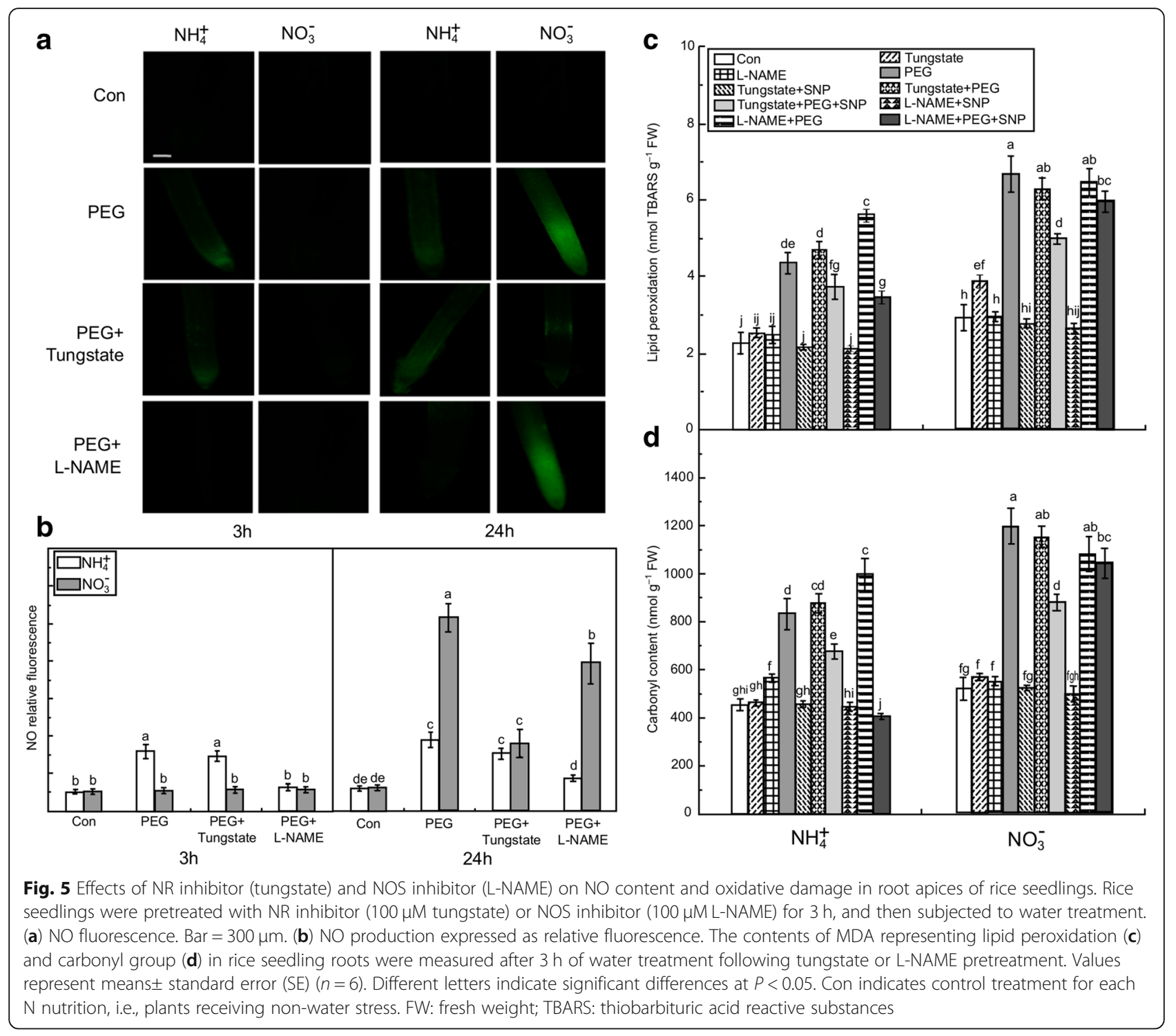

The effect of SNP on the alleviation of water stress-induced root oxidative damage was reversed after pretreatment with $100 \mu \mathrm{M} \mathrm{c}$-PTIO at $3 \mathrm{~h}$. Application of the NOS inhibitor L-NAME significantly aggravated water stress-induced oxidative damage in $\mathrm{NH}_{4}{ }^{+}$-treated roots, and SNP application reversed the effect of the NOS inhibitor but not that of the NR inhibitor (Fig. 5c, d). For the $\mathrm{NO}_{3}{ }^{-}$-treated roots, the application of NR inhibitor or NOS inhibitor had no significant effect on root oxidative damage relative to the water stress treatment.

Activities of antioxidative enzymes and nitrate/nitrite and arginine/citrulline metabolism

Water stress significantly enhanced the activities of the root antioxidant enzymes catalase (CAT), superoxide dismutase (SOD), ascorbate peroxidase (APX), and peroxidase (POD) by 107 and 38\%, 52 and 36\%, 152 and
$128 \%$, and 45 and $37 \%$ in the $\mathrm{NH}_{4}{ }^{+}$-treated roots and $\mathrm{NO}_{3}{ }^{-}$-treated roots, respectively, compared to their Con roots (Fig. 6). While SNP application further increased CAT, SOD, and APX activities (Fig. 6a-c), these antioxidant enzymes were inhibited by the application of the NO scavenger c-PTIO and by the NOS inhibitor L-NAME in the $\mathrm{NH}_{4}{ }^{+}$-treated roots under water stress.

As NR and NOS activities increased in the $\mathrm{NO}_{3}{ }^{-}$-treated roots, water stress lowered the nitrate level in the NR pathway and the arginine level in the NOS pathway (Additional file 3: Figure S3a, b). Similarly, application of NR inhibitor and NOS inhibitor enhanced root nitrate and arginine contents, respectively. In the $\mathrm{NH}_{4}{ }^{+}$-treated roots, water stress significantly decreased the arginine level, indicating that arginine metabolism is relatively high. In this treatment, NR inhibitor had no significant effect on root arginine content. On the other hand, the NOS 

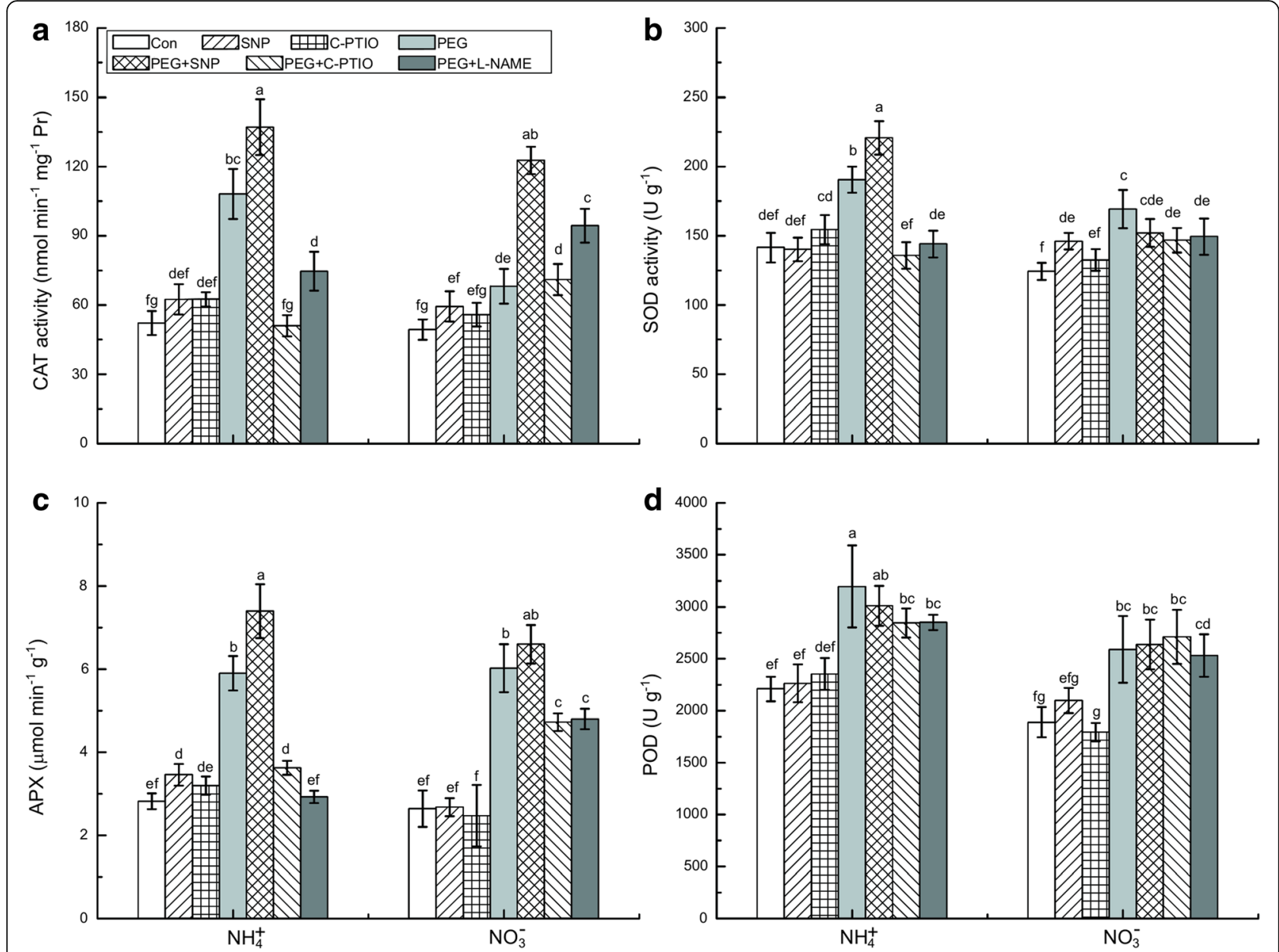

Fig. 6 Effects of different treatments on antioxidant enzyme changes in rice seedlings under water stress. Roots were collected to assay CAT (a), SOD (b), APX (c), and POD (d) after $3 \mathrm{~h}$ of treatment with non-water stress (Con) or water stress. For the c-PTIO, PEG + c-PTIO, and PEG + L-NAME treatments, the rice seedlings were pretreated with NO scavenger (c-PTIO) or NOS inhibitor (100 $\mu \mathrm{M}$ L-NAME) for $3 \mathrm{~h}$ followed by non-water stress or water stress. Values represent means \pm standard error $(\mathrm{SE})(n=6)$. Different letters indicate significant differences at $P<0.05$. Con indicates control treatment for each $\mathrm{N}$ nutrition, i.e., plants receiving non-water stress

inhibitor suppressed arginine metabolism, and thus the $\mathrm{NH}_{4}{ }^{+}$-treated roots had higher arginine levels than Con roots (Additional file 3: Figure S3c). These results also indirectly indicate that the $\mathrm{NO}$ early production burst in $\mathrm{NH}_{4}{ }^{+}$-treated roots might originate from the NOS pathway.

\section{Discussion}

Ample experimental evidence has demonstrated that $\mathrm{NO}$ is involved in plant abiotic stress [17]. However, to our knowledge, no detailed study has been conducted to evaluate the role of $\mathrm{NO}$ in drought acclimation in plants supplied with $\mathrm{NO}_{3}{ }^{-}$or $\mathrm{NH}_{4}{ }^{+}$. In the present study, plant biomass, root $\mathrm{N}$ uptake rate, and leaf photosynthesis were reduced after 21 days of water stress relative to the non-water stress condition (Fig. 1). However, these reductions were less severe for seedlings receiving $\mathrm{NH}_{4}{ }^{+}$, suggesting that $\mathrm{NH}_{4}{ }^{+}$nutrition can enhance drought tolerance in rice seedlings more effectively than $\mathrm{NO}_{3}{ }^{-}$ nutrition [2, 33]. Our study also demonstrated that, in the short term ( $48 \mathrm{~h})$, endogenous NO production in response to water stress is time-dependent, varying according to water stress duration and $\mathrm{N}$ nutrition. This finding is consistent with those reported for other stressors [10, 25]. Early NO bursts were induced at $3 \mathrm{~h}$ of water stress in the roots of $\mathrm{NH}_{4}{ }^{+}$-treated seedlings but not in $\mathrm{NO}_{3}{ }^{-}$-treated seedlings. Thus, there might be significant differences between $\mathrm{NH}_{4}{ }^{+}$- and $\mathrm{NO}_{3}{ }^{-}$-supplied plants in terms of $\mathrm{NO}$ signal-mediated drought tolerance. In addition, accumulation of ROS, such as $\mathrm{O}_{2}{ }^{-}$, $\mathrm{OH}^{-}$, and $\mathrm{H}_{2} \mathrm{O}_{2}$, and root oxidative damage were significantly lower in the $\mathrm{NH}_{4}{ }^{+}$-treated than in the $\mathrm{NO}_{3}{ }^{-}$-treated roots at $3 \mathrm{~h}$ of water stress (Fig. 4). Excessive accumulation of ROS damages cells and plasma membranes under the different abiotic stresses [11]. Whether the early NO burst in response to water stress observed in $\mathrm{NH}_{4}{ }^{+}$-supplied seedlings plays a crucial role 
in the plant antioxidant defense system needs further investigation, however.

The role of the early NO burst in the water stress tolerance of $\mathrm{NH}_{4}{ }^{+}-/ \mathrm{NO}_{3}{ }^{-}$-supplied seedlings was confirmed using $\mathrm{NO}$ donors and scavengers. Our study demonstrated that $\mathrm{NO}$ donor induced $\mathrm{NO}$ in the $\mathrm{NO}_{3}{ }^{-}$-treated roots at $3 \mathrm{~h}$ but not at $24 \mathrm{~h}$ of water stress (Fig. 3a). Plant ROS accumulation and MDA and carbonyl levels under water stress were significantly alleviated after the application of the NO donor in both $\mathrm{N}$ nutritions (Fig. 3c, d). Nevertheless, the levels of these substances were higher in the $\mathrm{NO}_{3}{ }^{-}$-treated roots than in the $\mathrm{NH}_{4}{ }^{+}$-treated roots. Therefore, the NO production enhanced at $3 \mathrm{~h}$ by the exogenous NO donor can alleviate water stress-induced oxidative damage in the $\mathrm{NO}_{3}{ }^{-}$-treated roots. On the other hand, elimination of the early NO burst by NO scavengers like c-PTIO significantly aggravated water stress-induced oxidative damage (Fig. 3c, d). These results provide direct evidence that the early NO burst plays a crucial role in drought tolerance in $\mathrm{NH}_{4}{ }^{+}$-treated roots. Because the $\mathrm{NH}_{4}{ }^{+}$-supplied roots maintained a higher $\mathrm{N}$ uptake rate than $\mathrm{NO}_{3}{ }^{-}$-supplied roots under water stress (Fig. 1f), we hypothesized that the higher $\mathrm{NH}_{4}{ }^{+}$uptake rate is beneficial for the early NO burst due to the NO production involved in root $\mathrm{N}$ metabolism [13, 34]. This NO burst can also be an active adaptation mechanism of plants to abiotic stress as, in addition to drought stress, it has been reported to occur repeatedly in plants challenged by pathogens [35], metal toxicity [9, 25], and cold stress [36].

Our study further demonstrated that an early NO burst improves plant drought tolerance by enhancing the antioxidant defense system of the root. Elevated plant antioxidant enzyme activities and gene expression levels in response to water stress have been widely demonstrated $[12,14,18]$. In the present study, the tips of the $\mathrm{NO}_{3}{ }^{-}$-treated roots presented more serious water stress-induced oxidative damage (due to the excessive production of $\mathrm{O}_{2}^{-}, \mathrm{OH}^{-}$, and $\mathrm{H}_{2} \mathrm{O}_{2}$ ) than those of the $\mathrm{NH}_{4}{ }^{+}$-treated roots (Figs. 2-4). In contrast, $\mathrm{NH}_{4}{ }^{+}$-supplied roots maintained relatively higher antioxidant enzyme (CAT, SOD, and APX) activity levels to catalyze $\mathrm{O}_{2}{ }^{-}$and $\mathrm{H}_{2} \mathrm{O}_{2}$ decomposition (Fig. 6). It has been demonstrated that there is significant crosstalk between NO and ROS in plants. The antioxidant function of $\mathrm{NO}$ was explained by its ability to reduce $\mathrm{H}_{2} \mathrm{O}_{2}$ and lipid peroxidation, and induce antioxidant gene expression and enzyme activity $[1,14]$. Our results showed that enhanced NO level and antioxidant enzyme activities (CAT and SOD) were significantly and simultaneously increased after $\mathrm{NO}$ donor application in $\mathrm{NO}_{3}{ }^{-}$-treated roots, thereby reducing ROS concentration and oxidative damage (Figs. 3, 6). The early $\mathrm{NO}$ burst observed in $\mathrm{NH}_{4}{ }^{+}$-treated roots can enhance antioxidant enzyme activity and ROS accumulation $\left(\mathrm{O}_{2}^{-{ }^{-}}, \mathrm{OH}^{-}\right.$, and $\left.\mathrm{H}_{2} \mathrm{O}_{2}\right)$. These results were confirmed by subsequent experimentation in which the application of NO scavenger significantly suppressed SOD and $\mathrm{CAT}$ in $\mathrm{NH}_{4}{ }^{+}$-treated roots. Thus, drought tolerance in the $\mathrm{NH}_{4}{ }^{+}$-treated roots might be associated with the NO-induced up-regulation of antioxidant enzymes and down-regulation of ROS accumulation.

Nitric oxide can also serve as a source of reactive nitrogen species (RNS). Overaccumulation of RNS under abiotic stress can cause tyrosine nitration and inactivate proteins like CAT, manganese-dependent (Mn-)SOD, and GR as well as the peroxidative activity of cytochrome $c[37,38]$. Our results showed that $\mathrm{NO}_{3}{ }^{-}$-supplied plants had more severe oxidative damage and accumulated extremely high $\mathrm{NO}$ levels after $24 \mathrm{~h}$ of water stress (Fig. 3). This latent NO production can be partially alleviated by replenishing the early NO burst at $3 \mathrm{~h}$ with SNP. These results indicate that both ROS and RNS metabolism participate in the water stress response. High $\mathrm{NO}$ accumulation in the $\mathrm{NO}_{3}{ }^{-}$-treated roots likely caused the nitrosative stress at $24 \mathrm{~h}$, which also damaged root redox balance. A similar phenomenon was described in plants subjected to cold [39], salinity [40], and drought [7] stresses. Because NO competes with oxygen for cytochrome $c$ oxidase binding (Complex IV), it affects both the respiratory chain and oxidative phosphorylation $[41,42]$. Thus, under water stress, the higher NO production in the $\mathrm{NO}_{3}{ }^{-}$-treated roots than in the $\mathrm{NH}_{4}{ }^{+}$-treated roots could aggravate respiratory inhibition and induce greater oxidative damage.

Our investigation further suggests that the early NO burst in $\mathrm{NH}_{4}{ }^{+}$-treated roots is mainly mediated by NOS at the early stages of water stress. Nitrate reductase-mediated NO generation is known to occur under water deficit $[19,43]$. Drought-induced NO generation by NOS-like enzymes in plants has also been demonstrated but this NO production pathway varies significantly with species, tissue type, and plant growth conditions $[29,30]$. For the $\mathrm{NH}_{4}{ }^{+}$-treated roots, both NOS activity and NO production increased simultaneously at $3 \mathrm{~h}$ of water stress, whereas the application of the NOS inhibitor completely repressed NO synthesis at this time point. The NOS inhibitor also aggravated water stress-induced membrane lipid peroxidation and oxidative protein damage, indicating that some NOS-associated proteins may play an important role in NO-mediated drought-protective responses $[8,23]$. In contrast, the NR inhibitor did not significantly affect NO production or membrane lipid peroxidation. The aggravation of lipid peroxidation by L-NAME may have been the result of the alteration of the NOS-mediated early $\mathrm{NO}$ burst. $\mathrm{In} \mathrm{NO}_{3}{ }^{-}$-treated roots, water stress enhanced NR activity significantly more than NOS activity at $24 \mathrm{~h}$. However, separate NR inhibitor and NOS inhibitor application only partially suppressed NO production. The NO produced by the NR pathway might 
therefore play an important role in later $\mathrm{NO}$ production $(24 \mathrm{~h})$, consistent with previous reports [18, 19]. Although several studies support the arginine-dependent NO production model in higher plants, the identification of genes encoding NOS in such plants is still up for debate [28]. For this reason, the nitrate/nitrite and arginine/citrulline levels in the NR and NOS pathways, respectively, were determined. It was found that water stress significantly increased NOS activity and accelerated the conversion of arginine to citrulline in both $\mathrm{N}$ nutritions. However, in relation to the
Con roots the arginine content was significantly enhanced in the $\mathrm{NH}_{4}{ }^{+}$-treated roots after application of the NOS inhibitor. These results provide additional evidence that the early $\mathrm{NO}$ burst in $\mathrm{NH}_{4}{ }^{+}$-treated roots is mainly mediated by NOS (Fig. 7).

\section{Conclusions}

Our study demonstrated that the early NO burst in $\mathrm{NH}_{4}{ }^{+}$-treated rice roots significantly enhanced plant antioxidant defense by reducing ROS accumulation and

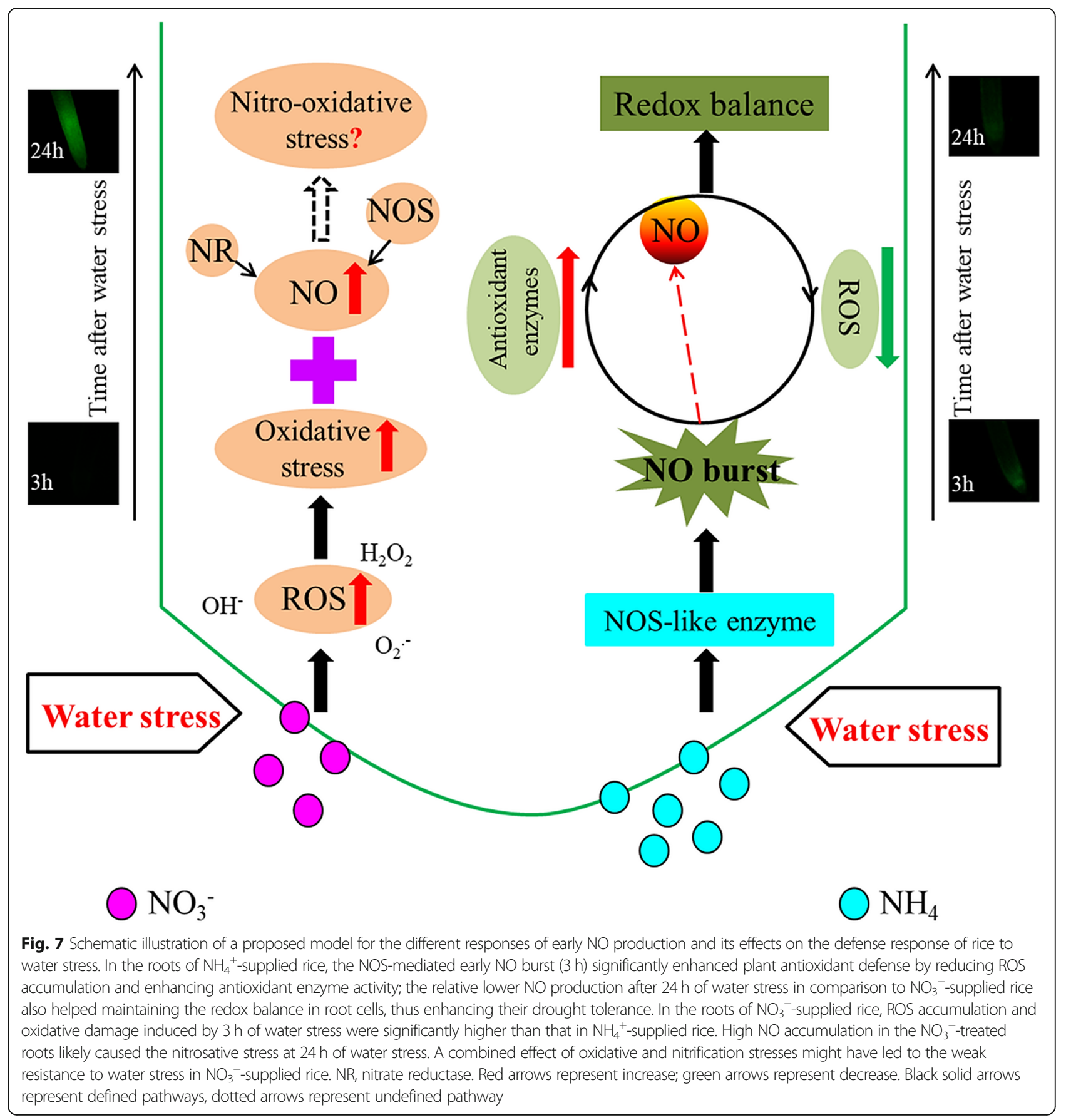


enhancing the activities of antioxidant enzymes, thereby increasing plants' acclimation to water stress. The early NO burst that occurs in response to water stress may be triggered by NOS-like enzymes in root. Our results provide new insight into how NO-signaling molecules modulate drought tolerance in $\mathrm{NH}_{4}{ }^{+}$-supplied rice plants. However, in future the definite evidencefor this pathway provided by genetic and molecular techniques still need to be developed to achieve the target-specific editing of NO biosynthetic and signaling pathways under water deficits.

\section{Methods}

\section{Plant material and growth conditions}

Rice (Oryza sativa L. 'Zhongzheyou No. 1' hybrid indica) seedlings, obtained from the China National Rice Research Institute, were grown hydroponically in a greenhouse. Seeds were sterilized in $1 \%(v / v)$ sodium hypochlorite solution. After germination, seeds were transferred to a $0.5 \mathrm{mM} \mathrm{CaCl}_{2}$ solution ( $\mathrm{pH}$ 5.5). Three days later, the seedlings were transferred to $1.5-\mathrm{L}$ black plastic pots containing a solution with the following composition: $\mathrm{NH}_{4} \mathrm{NO}_{3}(0.5 \mathrm{mM}), \mathrm{NaH}_{2} \mathrm{PO}_{4} \cdot 2 \mathrm{H}_{2} \mathrm{O}(0.18$ $\mathrm{mM}), \mathrm{KCl}(0.18 \mathrm{mM}), \mathrm{CaCl}_{2}(0.36 \mathrm{mM}), \mathrm{MgSO}_{4} \cdot 7 \mathrm{H}_{2} \mathrm{O}$ (0.6 mM), $\mathrm{MnCl}_{2} \cdot 4 \mathrm{H}_{2} \mathrm{O}(9 \mu \mathrm{M}), \mathrm{Na}_{2} \mathrm{MoO}_{4} \cdot 4 \mathrm{H}_{2} \mathrm{O}(0.1 \mu \mathrm{M})$, $\mathrm{H}_{3} \mathrm{BO}_{3}(10 \mu \mathrm{M}), \mathrm{ZnSO}_{4} \cdot 7 \mathrm{H}_{2} \mathrm{O}(0.7 \mu \mathrm{M}), \mathrm{CuSO}_{4}(0.3 \mu \mathrm{M})$, and $\mathrm{FeSO}_{4} \cdot 7 \mathrm{H}_{2} \mathrm{O}-\mathrm{EDTA}$ (ethylenediaminetetraacetic acid) $(20 \mu \mathrm{M})$. All experiments were performed in a controlled growth room under the following conditions: $14 / 10 \mathrm{~h}$ light/dark photoperiod, $400 \mu \mathrm{mol} \cdot \mathrm{m}^{-2} \cdot \mathrm{s}^{-1}$ light intensity, $28 / 23^{\circ} \mathrm{C}$ during the day and night, respectively, and $60 \%$ relative humidity. The solution $\mathrm{pH}$ was adjusted to 5.5

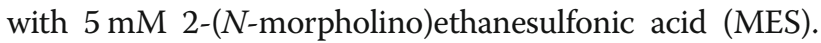
The solution was replaced every 3 days.

After 6 days, seedlings of similar size were cultivated under the four following treatments: $1 \mathrm{mM} \mathrm{NO}_{3}{ }^{-}, 1 \mathrm{mM}$ $\mathrm{NO}_{3}{ }^{-}+10 \%$ PEG (PEG-6000), $1 \mathrm{mM} \mathrm{NH}_{4}{ }^{+}$and $1 \mathrm{mM}$ $\mathrm{NH}_{4}{ }^{+}+10 \%$ PEG-6000. Water stress was induced by adding 10\% PEG-6000. Eight treatments were performed in the NO donor (SNP) experiments: $\mathrm{NH}_{4}{ }^{+}, \mathrm{NH}_{4}{ }^{+}+\mathrm{SNP}, \mathrm{NH}_{4}{ }^{+}+$ PEG-6000, $\mathrm{NH}_{4}{ }^{+}+$PEG-6000 + SNP, $\mathrm{NO}_{3}{ }^{-}, \mathrm{NO}_{3}{ }^{-}+\mathrm{SNP}$, $\mathrm{NO}_{3}{ }^{-}+\mathrm{PEG}-6000$, and $\mathrm{NO}_{3}{ }^{-}+\mathrm{PEG}-6000+\mathrm{SNP}$. The final SNP concentration was $20 \mu \mathrm{M}$. Each treatment had six replicates. For each $\mathrm{N}$ nutrition, plants cultivated under non-water stress condition were defined as the control (Con) relative to the water stress (PEG) condition.

To determine the role of $\mathrm{NO}$ in the plant antioxidant defense system under water stress, rice seedlings supplied with $1 \mathrm{mM} \mathrm{NO}_{3}{ }^{-}$or $1 \mathrm{mM} \mathrm{NH}_{4}{ }^{+}$solution were pretreated with $100 \mu \mathrm{M}$ c-PTIO (as NO scavenger) for $3 \mathrm{~h}$, and then subjected to non-water stress (Con treatment) or water stress (PEG) for $24 \mathrm{~h}$ under the same condition as those described above. Each treatment had six replicates.
To investigate the origin of the endogenous NO produced under water stress, rice seedlings supplied with 1 $\mathrm{mM} \mathrm{NO}_{3}{ }^{-}$or $1 \mathrm{mM} \mathrm{NH}_{4}{ }^{+}$solution were pretreated with the NR inhibitor (tungstate, $100 \mu \mathrm{M}$ ) or NOS inhibitor (L-NAME, $100 \mu \mathrm{M}$ ) for $3 \mathrm{~h}$, and then subjected to non-water stress (Con) or water stress for $24 \mathrm{~h}$ under the same conditions as described above. There were eight treatments for each $\mathrm{N}$ nutrition: tungstate, L-NAME, tungstate + SNP, PEG-6000 + tungstate, PEG-6000 + tungstate + SNP, L-NAME + SNP, PEG-6000 + L-NAME, and PEG-6000 + L-NAME + SNP. Each treatment had six replicates.

\section{Determination of $\mathrm{NO}$ and $\mathrm{ONOO}^{-}$contents}

The DAF-FM DA probe was used to determine the endogenous root NO level [25]. Root tips $(1 \mathrm{~cm})$ were incubated with $10 \mu \mathrm{M}$ DAF-FM DA in the dark for $30 \mathrm{~min}$, washed three times with $20 \mathrm{mM}$ HEPES-KOH ( $\mathrm{pH}$ 7.4) to remove excess fluorescence, and then observed and photographed under a Nikon Eclipse 80i fluorescence microscope (Nikon, Tokyo, Japan; excitation filter 460-500 nm, dichroic mirror $505 \mathrm{~nm}$, barrier filter 510-560). The relative fluorescence intensity was measured with Photoshop v. 7.0 (Adobe Systems, Mountain View, CA, USA).

Root endogenous $\mathrm{ONOO}^{-}$was determined using the aminophenylfluorescein (APF) probe method [44]. Root tips were incubated with $10 \mu \mathrm{M}$ APF dissolved in $10 \mathrm{mM}$ Tris- $\mathrm{HCl}(\mathrm{pH} 7.4)$ in the dark for $60 \mathrm{~min}$, and then washed three times with $10 \mathrm{mM}$ Tris- $\mathrm{HCl}$. Fluorescence images and relative fluorescence intensities were analyzed as described above for NO.

\section{Histochemical analyses}

Lipid peroxidation and root cell death were detected histochemically with Schiff's reagent and Evans blue [45]. Root tips were incubated in Schiff's reagent for $20 \mathrm{~min}$ and washed by three consecutive immersions in $0.5 \%$ $(w / v) \mathrm{K}_{2} \mathrm{O}_{3} \mathrm{~S}$ solution. A red/purple endpoint indicated the presence of aldehydes generated by lipid peroxidation. Roots were also washed by performing three serial immersions in distilled water, then incubated in $0.25 \%$ (w/v) Evans blue for $15 \mathrm{~min}$, and finally washed three times with distilled water. Roots stained with Schiff's reagent and Evans blue were immediately photographed under a Leica S6E stereomicroscope (Leica, Solms, Germany).

The oxidative damage level, specifically expressed as membrane lipid peroxidation and protein oxidative damage, was estimated by measuring the concentrations of MDA and carbonyl group with 2,4-dinitrophenylhydrazine (DNPH) [46].

\section{Determination of ROS contents}

Root $\mathrm{O}_{2}{ }^{-}$content was estimated using the method described in Liu et al. [47] with some modifications: about $0.15 \mathrm{~g}$ fresh root was powdered with $2 \mathrm{~mL}$ of $65 \mathrm{mM}$ 
phosphate buffer saline (PBS, pH 7.8) in a pre-cooled mortar, and centrifuged at $5000 \mathrm{~g}$ and $4{ }^{\circ} \mathrm{C}$ for $10 \mathrm{~min}$. Then, $0.9 \mathrm{~mL}$ of $65 \mathrm{mM}$ PBS (pH 7.8) and $0.1 \mathrm{~mL}$ of $10 \mathrm{mM}$ hydroxylammonium chloride were added to $1 \mathrm{~mL}$ of the root extract supernatant, thoroughly mixed, and left to react for $25 \mathrm{~min}$. After this period, $1 \mathrm{~mL}$ of $1 \%(w / v)$ sulfanilamide and $1 \mathrm{~mL}$ of $0.02 \%(\mathrm{w} / \mathrm{v}) \mathrm{N}$-(1-naphthyl)-ethylenediaminedihydrochloride were added to $1 \mathrm{~mL}$ of root extract solution and left to react for $30 \mathrm{~min}$. Absorbance was then measured at $540 \mathrm{~nm}$.

Root $\mathrm{H}_{2} \mathrm{O}_{2}$ content was determined by the photocolorimetric method [48]: $\sim 0.15 \mathrm{~g}$ fresh root was powdered with $2 \mathrm{~mL}$ acetone in a pre-cooled mortar, and centrifuged at $5000 \mathrm{~g}$ and $4{ }^{\circ} \mathrm{C}$ for $10 \mathrm{~min}$. Then, $0.1 \mathrm{~mL}$ of $5 \%(\mathrm{w} / \mathrm{v}) \mathrm{TiSO}_{4}$ and $0.1 \mathrm{~mL}$ pre-cooled ammonium hydroxide were added to $1 \mathrm{~mL}$ of the root extract supernatant, which was re-centrifuged at $5000 \mathrm{~g}$ for $10 \mathrm{~min}$. The supernatant was discarded and the sediment was re-dissolved in $4 \mathrm{~mL}$ of $2 \mathrm{M} \mathrm{H}_{2} \mathrm{SO}_{4}$. The absorbance of the root extract solution was measured at $415 \mathrm{~nm}$.

Root $\mathrm{OH}^{-}$content was analyzed by the methods described in a previous study [49]: $\sim 0.1 \mathrm{~g}$ fresh root was powdered with $3 \mathrm{~mL}$ of $50 \mathrm{mM}$ PBS (pH 7.0) in a mortar, and centrifuged at $10,000 \mathrm{~g}$ and $4{ }^{\circ} \mathrm{C}$ for $10 \mathrm{~min}$. Then, $1.0 \mathrm{~mL}$ of $25 \mathrm{mM}$ PBS (pH 7.0) containing $5 \mathrm{mM}$ 2-deoxy- $D$-ribose and $0.2 \mathrm{mM} \mathrm{NADH}$ were added to 1 $\mathrm{mL}$ of the root extract supernatant, completely blended, and left to react for $60 \mathrm{~min}$ at $35^{\circ} \mathrm{C}$ in the dark. Following this incubation, $1 \mathrm{~mL}$ of $1 \%(\mathrm{w} / \mathrm{v})$ thiobarbituric acid and $1 \mathrm{~mL}$ glacial acetic acid were added to the filtrate. The mixture was heated to $100^{\circ} \mathrm{C}$ for $30 \mathrm{~min}$ and then placed on ice for $20 \mathrm{~min}$. The absorbance of the root extract solution was then measured at $532 \mathrm{~nm}$, and the $\mathrm{OH}^{-}$content was inferred from the production of MDA.

\section{Determination of enzyme activities}

Fresh rice root samples $(0.5 \mathrm{~g})$ were homogenized in 5 $\mathrm{mL}$ of $10 \mathrm{mM}$ phosphate buffer ( $\mathrm{pH} 7.0$ ) containing $4 \%$ $(\mathrm{w} / \mathrm{v})$ polyvinylpyrrolidone and $1 \mathrm{mM}$ ethylenediaminetetraacetic acid. The supernatant was used as crude enzyme solution and collected by centrifugation at $12,000 \mathrm{~g}$ and $4{ }^{\circ} \mathrm{C}$ for $15 \mathrm{~min}$. The activities of SOD, CAT, APX, and POD were estimated using the photocolorimetric methods described in Jiang and Zhang [11], and Sachadyn-Krol et al. [50].

Root NR and NOS activities were assayed using the methods described in previous studies [25, 26], with some modifications. Briefly, total protein was extracted using a buffer containing $100 \mathrm{mM}$ HEPES-KOH (pH 7.5), $1 \mathrm{mM}$ EDTA, 10\% (v/v) glycerol, $5 \mathrm{mM}$ 1,4-dithiothreitol (DTT), $0.5 \mathrm{mM}$ phenylmethylsulfonyl fluoride, $0.1 \%$ Triton X-100 (v/v), 1\% polyvinylpyrrolidone (PVP), and $20 \mu \mathrm{M}$ flavin adenine dinucleotide. The supernatant was collected by centrifugation at $12,000 \mathrm{~g}$ and $4{ }^{\circ} \mathrm{C}$ for $20 \mathrm{~min}$, and then used to determine the NR and NOS activities at $520 \mathrm{~nm}$ and $340 \mathrm{~nm}$, respectively.

Specifically, the activity of NR was measured immediately by mixing $250 \mu \mathrm{L}$ of supernatant with $250 \mu \mathrm{L}$ pre-warmed $\left(25^{\circ} \mathrm{C}\right)$ assay buffer containing $50 \mathrm{mM}$ HEPES-KOH (pH 7.5), $10 \mathrm{mM} \mathrm{MgCl}_{2}, 1 \mathrm{mM}$ DTT, $2 \mathrm{mM}$ $\mathrm{KNO}_{3}$ and $200 \mu \mathrm{M} \mathrm{NADH}$. The reaction was started by adding assay buffer, incubated at $30^{\circ} \mathrm{C}$ for $30 \mathrm{~min}$ and then stopped by adding $50 \mu \mathrm{L} 0.5 \mathrm{M} \mathrm{Zn}$-acetate. The nitrite produced was measured colorimetrically at $540 \mathrm{~nm}$ after adding 1 mlof $1 \%$ sulfanilamide in $3 \mathrm{M} \mathrm{HCl}$ plus $1 \mathrm{~mL}$ of $0.02 \% \mathrm{~N}$-(1-naphthyl)ethylenediamine in $0.2 \mathrm{M} \mathrm{HCl}$. NOS activity was detected in $1 \mathrm{~mL}$ of reaction mixture containing $100 \mathrm{mM}$ phosphate buffer (pH 7.0), $1 \mathrm{mM}$ laevo-arginine(L-Arg), $2 \mathrm{mM} \mathrm{MgCl}_{2}, 0.3 \mathrm{mM} \mathrm{CaCl}, 4 \mu \mathrm{M}$ $\mathrm{BH}_{4}, 1 \mu \mathrm{M}$ FAD, $1 \mu \mathrm{M}$ flavin mononucleotide (FMN), 0.2 $\mathrm{mM}$ DTT, $0.2 \mathrm{mM} \mathrm{NADPH}$, and $200 \mu \mathrm{L}$ of protein extract. The decrease in absorbance as a result of NADPH consumption was determined at $340 \mathrm{~nm}$ for $5 \mathrm{~min}$. NOS activity was calculated using the extinction coefficient of $\operatorname{NADPH}\left(\varepsilon=6.22 \mathrm{mM}^{-1} \cdot \mathrm{cm}^{-1}\right)$.

\section{Determination of arginine and citrulline}

Arginine and citrulline contents were estimated using the method described in Salazar et al. [51]. Briefly, $1.0 \mathrm{~g}$ root samples were frozen in liquid $\mathrm{N}_{2}$ and extracted with $4 \mathrm{~mL} 80 \%(\mathrm{v} / \mathrm{v})$ methanol, and then centrifuged at $10,000 \mathrm{~g}$ and $4{ }^{\circ} \mathrm{C}$ for $5 \mathrm{~min}$. The supernatant was then used in derivatization and reaction processes. Serial concentrations of amino acid standards were prepared as described above for the derivatizing reagent, and the derivatizing samples were used to determine the arginine and citrulline contents using liquid chromatography/electrospray ionization tandem mass spectroscopy (LC-ESI-MS).

\section{Statistical analyses}

All experiments conducted in this study were performed in six replicates, at least. All data, expressed as means \pm standard error (SE), were processed in SPSS v. 13.0 (IBM Corp., Armonk, NY, USA). The Least Significant Difference (LSD) test was used to determine statistical significant differences among the treatments $(P<0.05)$. Figures were drawn in Origin v. 8.0 (OriginLab Corporation, Northampton, MA, USA).

\section{Additional files}

Additional file 1: Figure S1. Effect of exogenous NO donor (SNP) on root oxidative damage under water stress. Rice roots were exposed to mixed $\mathrm{N}\left(\mathrm{NH}_{4}{ }^{+}+\mathrm{NO}_{3}{ }^{-}\right)$nutrient solution containing $0 \mu \mathrm{M}, 5 \mu \mathrm{M}, 10 \mu \mathrm{M}$, $20 \mu \mathrm{M}, 40 \mu \mathrm{M}, 80 \mu \mathrm{M}$, or $100 \mu \mathrm{M}$ SNP either with or without 10\% PEG for $48 \mathrm{~h}$. The contents of MDA representing lipid peroxidation (a) and carbonyl group (b) in rice seedling roots were determined. Values represent means \pm SE $(n=6)$. Different letters indicate significant differences at $P<0.05$. Con indicates control treatment for each $N$ 
nutrition, i.e., plants receiving non-water stress. FW: fresh weight: TBARS: thiobarbituric acid reactive substances. (TIF $71 \mathrm{~kb}$ )

Additional file 2: Figure S2. Effect of water stress on NR (a) and NOS (b) in roots. Roots were collected for the NR and NOS assays after $3 \mathrm{~h}$ and $24 \mathrm{~h}$ of water stress, respectively. Values represent means $\pm \mathrm{SE}(n=$ 6). Different letters indicate significant differences at $P<0.05$. Con indicates control treatment for each $\mathrm{N}$ nutrition, i.e., plants receiving nonwater stress. (TIF $41 \mathrm{~kb}$ )

Additional file 3: Figure S3. Effect of exogenous NR inhibitor (tungstate) and NOS inhibitor (L-NAME) on the related compounds in NR-mediated and NOS-mediated NO pathways. (a) Levels of nitrate and nitrite in $\mathrm{NO}_{3}^{-}$-treated roots. (b) Levels of arginine and citrulline in $\mathrm{NO}_{3}{ }^{-}$ treated roots. (c) Levels of arginine and citrulline in $\mathrm{NH}_{4}{ }^{+}$-treated roots. For the PEG + tungstate and PEG + L-NAME treatments, the rice seedlings were pretreated with NR inhibitor (100 $\mu \mathrm{M}$ tungstate) or NOS inhibitor (100 $\mu \mathrm{M} \mathrm{L-NAME)} \mathrm{for} 3 \mathrm{~h}$, followed by non-water stress (Con) or water stress treatment. Values represent means \pm SE $(n=6)$. Different letters indicate significant differences at $P<0.05$. (TIF $69 \mathrm{~kb}$ )

Additional file 4: Method S1. Determination of leaf photosynthesis, root $\mathrm{N}$ uptake rate, and root nitrate and nitrite contents in rice seedlings after 21 days of non-water stress (Con) or water stress (PEG) treatment. (DOCX $14 \mathrm{~kb})$

\section{Abbreviations}

ABA: Abscisic acid; APF: Aminophenylfluorescein; APX: Ascorbate peroxidase; CAT: Catalase; c-PTIO: 2-(4-carboxyphenyl)-4,4,5,5-tetramethylimidazoline-1oxyl-3-oxide; DAF-FM DA: Diaminofluorescein-FM diacetate; DNPH: 2,4dinitrophenylhydrazine; DTT: 1,4-dithiothreitol;

EDTA: Ethylenediaminetetraacetic acid; FAD: Flavin adenine dinucleotide; FMN: Flavin mononucleotide; GR: Glutathione reductase; GSNO: Snitrosoglutathione; L-Arg: Leavo-arghinine; LC-ESI-MS: Liquid chromatography/electrospray ionization tandem mass spectroscopy; LNAME: N(G)-nitro-L-arginine methyl ester; MDA: Malondialdehyde; MES: 2-(Nmorpholino)ethanesulfonic acid; NADPH: Nicotinamide adenine dinucleotide phosphate; NO: Nitric oxide; NOS: Nitric oxide synthase; NR: Nitrate reductase; $\mathrm{ONOO}^{-}$: Peroxynitrite; PBS: Phosphate buffer saline; PEG: Polyethylene glycol; $P_{\mathrm{n}}$ : Net photosynthetic rate; POD: Peroxidase; PVP: Polyvinylpyrrolidone; RNS: Reactive nitrogen species; ROS: Reactive oxygen species; SNP: Sodium nitroprusside; SOD: Superoxide dismutase

\section{Acknowledgements}

We would like to thank Editage (http://www.editage.cn) for English language editing.

\section{Funding}

This work was supported by the Natural Science Foundation of Zhejiang Province (Grant no. LY18C130005); and the National Key Research and Development Program of China (Grant no. 2017YFD0300100, 2016YFD0101801). The supporters did not play any role in the design, analysis, or interpretation of this study and the relevant data.

\section{Availability of data and materials}

All data generated or analysed during this study are included in this published article (and its supplementary information files).

\section{Authors' contributions}

XCC, QXM, and QYJ conceived and designed the experiments. XCC, CQZ, and $\mathrm{CZ}$ performed the experiments. XCC, LHW, and $\mathrm{JHZ}$ analyzed the data. XCC, QXM, and CQZ wrote the paper. All authors read and approved the final manuscript.

\section{Ethics approval and consent to participate} Not applicable.

\section{Consent for publication}

Not applicable.

\section{Competing interests}

The authors have declared that no competing interests exist.

\section{Publisher's Note}

Springer Nature remains neutral with regard to jurisdictional claims in published maps and institutional affiliations.

Received: 30 October 2018 Accepted: 14 March 2019

Published online: 20 March 2019

\section{References}

1. Bogeat-Triboulot MB, Brosché M, Renaut J, Jouve L, Le Thiec D, Fayyaz $P$, Vinocur B, Witters E, Laukens K, Teichmann T, Altman A, Hausman J, Polle A, Kangasjärvi J, Dreyer E. Gradual soil water depletion results in reversible changes of gene expression, protein profiles, ecophysiology, and growth performance in Populuseuphratica, a poplar growing in arid regions. Plant Physiol. 2007;143:876-92.

2. Guo S, Zhou Y, Shen Q, Zhang F. Effect of ammonium and nitrate nutrition on some physiological processes in higher plants - growth, photosynthesis, photorespiration, and water relations. Plant Biol (Stuttg). 2007:9:21-9.

3. Slewinski TL. Non-structural carbohydrate partitioning in grass stems: a target to increase yield stability, stress tolerance, and biofuel production. J Exp Bot. 2012;63:4647-70.

4. Neill SJ, Desikan R, Hancock JT. Nitric oxide signalling in plants. New Phytol. 2003;159:11-35.

5. Wilson ID, Neill SJ, Hancock JT. Nitric oxide synthesis and signalling in plants. Plant Cell Environ. 2007;31:622-31.

6. Simontacchi M, Galatro A, Ramos-Artuso F, Santa-María GE. Plant survival in a changing environment: the role of nitric oxide in plant responses to abiotic stress. Front Plant Sci. 2015;6:977.

7. Signorelli S, Corpas FJ, Omar Borsani O, Barroso JB, Monza J. Water stress induces a differential and spatially distributed nitro-oxidative stress response in roots and leaves of Lotus japonicus. Plant Sci. 2013;201(202):137-46.

8. Zhao M, Tian Q, Zhang W. Nitric oxide synthase-dependent nitric oxide production is associated with salt tolerance in Arabidopsis. Plant Physiol. 2007;144:206-17.

9. González A, Cabrera ML, Henríquez MJ, Contreras RA, Morales B, Moenne A. Cross talk among calcium, hydrogen peroxide, and nitric oxide and activation of gene expression involving calmodulins and calciumdependent protein kinases in Ulva compress a exposed to copper excess. Plant Physiol. 2012;158:1451-62.

10. Planchet E, Verdu I, Delahaie J, Cukier C, Girard C, Morère-Le Paven M-C, Limami AM. Abscisic acid-induced nitric oxide and proline accumulation in independent pathways under water-deficit stress during seedling establishment in Medicagotruncatula. J Exp Bot. 2014;65:2161-70.

11. Jiang $M$, Zhang J. Water stress-induced abscisic acid accumulation triggers the increased generation of reactive oxygen species and up-regulates the activities of antioxidant enzymes in maize leaves. J Exp Bot. 2002;53:2401-10.

12. Fan H, Li T, Guan L, Li Z, Guo N, Cai Y, Li Y. Effects of exogenous nitric oxide on antioxidation and DNA methylation of Dendrobium huoshanense grown under drought stress. Plant Cell Tissue Organ Cult. 2012;109:307-14.

13. Del Río LA. ROS and RNS in plant physiology: an overview. J Exp Bot. 2015; 66:2827-37.

14. Farooq M, Basra SMA, Wahid A, Rehman H. Exogenously applied nitric oxide enhances the drought tolerance in fine grain aromatic rice (Oryza sativa L.). J Agron Crop Sci. 2009;195:254-61.

15. Verdoy D, Coba De La Peña T, Redondo FJ, Lucas MM, Pueyo JJ. Transgenic Medicagotruncatula plants that accumulate proline display nitrogen-fixing activity with enhanced tolerance to osmotic stress. Plant Cell Environ. 2006; 29:1913-23.

16. Zhang A, Jiang M, Zhang J, Ding H, Xu S, Hu X, Tang M. Nitric oxide induced by hydrogen peroxide mediates abscisic acid-induced activation of the mitogen-activated protein kinase cascade involved in antioxidant defense in maize leaves. New Phytol. 2007;175:36-50.

17. Santisree $P$, Bhatnagar-Mathur $P$, Sharma KK. NO to drought-multifunctional role of nitric oxide in plant drought: do we have all the answers? Plant Sci. 2015;239:44-55.

18. Arasimowicz-Jelonek M, Floryszak-Wieczorek J, Kubiś J. Involvement of nitric oxide in water stress-induced responses of cucumber roots. Plant Sci. 2009; 177:682-90.

19. Arasimowicz-Jelonek M, Floryszak-Wieczorek J, Kubiś J. Interaction between polyamine and nitric oxide signaling in adaptive responses to drought in cucumber. J Plant Growth Regul. 2009;28:177-86. 
20. Groß F, Durner J, Gaupels F. Nitric oxide, antioxidants and prooxidants in plant defence responses. Front Plant Sci. 2013;4:419.

21. Corpas FJ, del Río LA, Barroso JB. Need of biomarkers of nitrosative stress in plants. Trends Plant Sci. 2007;12:436-8.

22. Liao W, Huang G, Yu J, Zhang M. Nitric oxide and hydrogen peroxide alleviate drought stress in marigold explants and promote its adventitious root development. Plant Physiol Biochem. 2012;58:6-15.

23. Guo FQ, Okamoto M, Crawford NM. Identification of a plant nitric oxide synthase gene involved in hormonal signaling. Science. 2003;302:100-3.

24. Shi F, Li Y. Verticilliumdahliae toxins-induced nitric oxide production in Arabidopsis is major dependent on nitrate reductase. BMB Rep. 2008;41:79-85.

25. Sun C, Lu L, Liu L, Liu W, Yu Y, Liu X, Jin C, Lin X. Nitrate reductasemediated early nitric oxide burst alleviates oxidative damage induced by aluminum through enhancement of antioxidant defenses in roots of wheat (Triticumaestivum). New Phytol. 2014;201:1240-50.

26. Zhao M, Chen L, Zhang L, Zhang W. Nitric reductase-dependent nitric oxide production is involved in cold acclimation and freezing tolerance in Arabidopsis. Plant Physiol. 2009;151:755-67.

27. Freschi L, Rodrigues MA, Domingues DS, Purgatto E, Van Sluys MA, Magalhaes JR, Kaiser WM, Mercier H. Nitric oxide mediates the hormonal control of Crassulacean acid metabolism expression in young pineapple plants. Plant Physiol. 2010;152:1971-85.

28. Zemojtel T, Fröhlich A, Palmieri MC, Kolanczyk M, Mikula I, Wyrwicz LS Wanker EE, Mundlos S, Vingron M, Martasek P, Durner J. Plant nitric oxide synthase: a never-ending story? Trends Plant Sci. 2006;11:524-5.

29. Corpas FJ, Palma JM, del Río LA, Barroso JB. Evidence supporting the existence of L-arginine-dependent nitric oxide synthase activity in plants. New Phytol. 2009;184:9-14.

30. Shi H, Ye T, Zhu JK, Chan Z. Constitutive production of nitric oxide leads to enhanced drought stress resistance and extensive transcriptional reprogramming in Arabidopsis. J Exp Bot. 2014;65:4119-31.

31. Yang X, Li Y, Ren B, Ding L, Gao C, Shen Q, Guo S. Drought-induced root aerenchyma formation restricts water uptake in rice seedlings supplied with nitrate. Plant Cell Physiol. 2012;53:495-504.

32. Ding L, Gao C, Li Y, Li Y, Zhu Y, Xu G, Shen Q, Kaldenhoff R, Kai L, Guo S. The enhanced drought tolerance of rice plants under ammonium is related to aquaporin (AQP). Plant Sci. 2015;234:14-21.

33. Li Y, Ren B, Yang X, Xu G, Shen Q, Guo S. Chloroplast downsizing under nitrate nutrition restrained mesophyll conductance and photosynthesis in rice (Oryza sativa L.) under drought conditions. Plant Cell Physiol. 2012;53: 892-900.

34. Corpas FJ, Chaki M, Fernández-Ocaña A, Valderrama R, Palma JM, Carreras A, Begara-Morales JC, Airaki M, Del Río LA, Barroso JB. Metabolism of reactive nitrogen species in pea plants under abiotic stress conditions. Plant Cell Physiol. 2008;49:1711-22.

35. Floryszak-Wieczorek J, Arasimowicz M, Milczarek G, Jelen H, Jackowiak H. Only an early nitric oxide burst and the following wave of secondary nitric oxide generation enhanced effective defence responses of pelargonium to a necrotrophic pathogen. New Phytol. 2007;175:718-30.

36. Cantrel C, Vazquez T, Puyaubert J, Rezé N, Lesch M, Kaiser WM, Dutilleul C, Guillas I, Zachowski A, Baudouin E. Nitric oxide participates in coldresponsive phosphosphingolipid formation and gene expression in Arabidopsis thaliana. New Phytol. 2011;189:415-27.

37. Clark D, Durner J, Navarre DA, Klessig DF. Nitric oxide inhibition of tobacco catalase and ascorbate peroxidase. Mol Plant-Microbe Interact. 2000:13:1380-4.

38. Batthyány C, Souza JM, Durán R, Cassina A, Cerveñansky C, Radi R. Time course and site(s) of cytochrome $c$ tyrosine nitration by peroxynitrite. Biochemistry. 2005:44:8038-46.

39. Airaki M, Leterrier M, Mateos RM, Valderrama R, Chaki M, Barroso JB, Del Río LA, Palma JM, Corpas FJ. Metabolism of reactive oxygen species and reactive nitrogen species in pepper (Capsicum annuum L.) plants under low-temperature stress. Plant Cell Environ. 2012;35:281-95.

40. Tanou G, Filippou P, Belghazi M, Job D, Diamantidis G, Fotopoulos V, Molassiotis A. Oxidative and nitrosative-based signaling and associated post-translational modifications orchestrate the acclimation of citrus plants to salinity stress. Plant J. 2012;72:585-99.

41. Millar AH, Day DA. Nitric oxide inhibits the cytochrome oxidase but not the alternative oxidase of plant mitochondria. FEBS Lett. 1996;398:155-8.

42. Yamasaki $H$, Shimoji $H$, Ohshiro $Y$, Sakihama Y. Inhibitory effects of nitric oxide on oxidative phosphorylation in plant mitochondria. Nitric Oxide. 2001;5:261-70
43. Yu M, Lamattina L, Spoel SH, Loake GJ. Nitric oxide function in plant biology: a redox cue in deconvolution. New Phytol. 2014;202:1142-56.

44. Saito S, Yamamoto-Katou A, Yoshioka H, Doke N, Kawakita K. Peroxynitrite generation and tyrosine nitration in defense responses in tobacco BY-2 cells. Plant Cell Physiol. 2006;47:689-97.

45. Yamamoto $Y$, Kobayashi $Y$, Matsumoto $\mathrm{H}$. Lipid peroxidation is an early symptom triggered by aluminum, but not the primary cause of elongation inhibition in pea roots. Plant Physiol. 2001;125:199-208.

46. Velikova V, Yordanov I, Edreva A. Oxidative stress and some antioxidant systems in acid rain-treated bean plants: protective role of exogenous polyamines. Plant Sci. 2000;151:59-66.

47. Liu Y, Wu R, Wan Q, Xie G, Bi Y. Glucose-6-phosphate dehydrogenase plays a pivotal role in nitric oxide-involved defense against oxidative stress under salt stress in red kidney bean roots. Plant Cell Physiol. 2007:48:511-22.

48. Wang H, Huang J, Bi Y. Nitrate reductase-dependent nitric oxide production is involved in aluminum tolerance in red kidney bean roots. Plant Sci. 2010; 179:281-8.

49. Liu $Y$, Jiang $H$, Zhao $Z$, An L. Nitric oxide synthase like activity-dependent nitric oxide production protects against chilling-induced oxidative damage in Chorisporabungeana suspension cultured cells. Plant Physiol Biochem. 2010;48:936-44.

50. Sachadyn-Król M, Materska M, Chilczuk B, Karás M, Jakubczyk A, Perucka I, Jackowska I. Ozone-induced changes in the content of bioactive compounds and enzyme activity during storage of pepper fruits. Food Chem. 2016;211:59-67.

51. Salazar C, Armenta JM, Shulaev V. An UPLC-ESI-MS/MS assay using 6aminoquinolyl- $\mathrm{N}$-hydroxysuccinimidyl carbamate derivatization for targeted amino acid analysis: application to screening of Arabidopsis thaliana mutants. Metabolites. 2012;2:398-28.

\section{Ready to submit your research? Choose BMC and benefit from:}

- fast, convenient online submission

- thorough peer review by experienced researchers in your field

- rapid publication on acceptance

- support for research data, including large and complex data types

- gold Open Access which fosters wider collaboration and increased citations

- maximum visibility for your research: over $100 \mathrm{M}$ website views per year

At $\mathrm{BMC}$, research is always in progress.

Learn more biomedcentral.com/submissions 